ARTICLE

\title{
Virus-like glycodendrinanoparticles displaying quasi-equivalent nested polyvalency upon glycoprotein platforms potently block viral infection
}

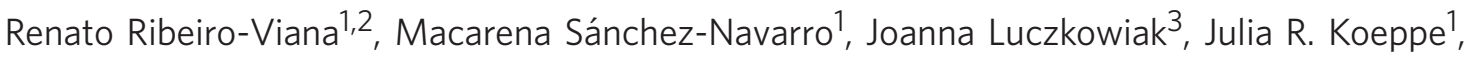
Rafael Delgado ${ }^{3}$, Javier Rojo ${ }^{2} \&$ Benjamin G. Davis ${ }^{1}$

Ligand polyvalency is a powerful modulator of protein-receptor interactions. Host-pathogen infection interactions are often mediated by glycan ligand-protein interactions, yet its interrogation with very high copy number ligands has been limited to heterogenous systems. Here we report that through the use of nested layers of multivalency we are able to assemble the most highly valent glycodendrimeric constructs yet seen (bearing up to 1,620 glycans). These constructs are pure and well-defined single entities that at diameters of up to $32 \mathrm{~nm}$ are capable of mimicking pathogens both in size and in their highly glycosylated surfaces. Through this mimicry these glyco-dendri-protein-nano-particles are capable of blocking (at picomolar concentrations) a model of the infection of T-lymphocytes and human dendritic cells by Ebola virus. The high associated polyvalency effects $\left(\beta>10^{6}, \beta / N \sim 10^{2}-10^{3}\right)$ displayed on an unprecedented surface area by precise clusters suggest a general strategy for modulation of such interactions.

\footnotetext{
${ }^{1}$ Department of Chemistry, University of Oxford, Chemistry Research Laboratory, 12 Mansfield Road, Oxford OX1 3TA, UK. ${ }^{2}$ Glycosystems Laboratory, Instituto de Investigaciones Químicas (IIQ), CSIC-Universidad de Sevilla, Américo Vespucio 49, Seville 41092, Spain. ${ }^{3}$ Laboratorio de Microbiología Molecular, Instituto de Investigación Hospital 12 de Octubre (imas12), Madrid 28041, Spain. Correspondence and requests for materials should be addressed to R.D. (email: rdelgado.hdoc@salud.madrid.org) or to J.R. (email: javier.rojo@iiq.csic.es) or to B.G.D. (email: ben.davis@chem.ox.ac.uk).
} 
T he initial stages of an infectious process are crucial for subsequent immune response and elimination of pathogens ${ }^{1}$. The innate immune system comprises mechanisms and specialized cells responsible for first contact with external biological agents ${ }^{2}$. Detection of invaders via pathogen recognition receptors and subsequent activation of antimicrobial defences triggers specific antigen responses ${ }^{3}$. DC-SIGN (dendritic cellspecific intercellular adhesion molecule-3-grabbing nonintegrin) receptor is one of the most important pathogen recognition receptor. It is expressed mainly on the surface of dendritic cells (DCs), and some subtypes of macrophages ${ }^{4}$. DC-SIGN recognizes in a multivalent manner mannose and fucose containing glycoproteins ${ }^{5}$, such as ICAM-3 (intercellular adhesion molecule 3) present in $\mathrm{T}$ cells, and envelope glycoproteins found on pathogens ${ }^{6}$. By using DC-SIGN as an entry point some viruses are capable of escaping from the processing and degradation events carried out by the immune defence machinery at antigen-presenting cells ${ }^{7}$. Therefore, the inhibition of pathogen entry through the blockade of this receptor at early stages of infection is one strategy for new antiviral agents.

Several studies have been directed towards the preparation of synthetic carbohydrate systems able to block or stimulate DC$\mathrm{SIGN}^{8-21}$. Despite their elegant design, one of the problems that these artificial systems face is achieving adequate size and multivalency to sufficiently mimic natural systems such as viruses or other pathogens while maintaining full control of shape and structure $^{16}$. Indeed, ligand valencies beyond 32 (refs 9,18) have not been possible before with full control (Indeed, valencies $>100$ are rare in any glycodendrimeric structure. See the following references André et al. ${ }^{22}$ and Camponovo et al. ${ }^{23}$ for examples of 128-mer lactoside and 243-mer xyloside display, respectively. ${ }^{22,23}$.

We have previously demonstrated that symmetrically multivalent glycan ligands mounted on protein platforms (glycodendriproteins) are useful tools to study carbohydrate-protein interactions and are able to control or modulate a desired response ${ }^{24-27}$. Other dendrimeric displays on proteins have also been explored subsequently ${ }^{28-30}$. However, to date, this approach has provided only limited carbohydrate valency levels on single protein platforms. We envisaged that a controlled design for a highly polyvalent protein display of sugars might be achieved through a novel strategy of 'nested polyvalency' (polyvalent display of polyvalency) (Fig. 1a).

We describe here the realization of this approach through the multivalent assembly of protein monomers themselves carrying polyvalent glycan display motifs (glycodendrons). The resulting glycodendriprotein homomultimers display many glycans in a precise manner. Consistent with associated guiding physical principles $^{31-33}$, these constructs therefore display symmetry and pseudosymmetry at both the level of protein assembly and glycodendron. These synthetic glycoprotein assemblies display the highest known number of glycans $(n=1,620)$ yet presented in a homogeneous manner. We have applied this idea (Fig. 1) here to the inhibitory immunomodulation of a DC-SIGN-pathogen glycoprotein interaction (Fig. 1b).

\section{Results}

Construction of glyco-dendri-protein-nano-particles. We reasoned that assembly of an entity with similar dimensions (in the form of a self-assembled protein sphere-like icosahedron $\mathrm{Q} \beta^{34}$, $\sim 28 \mathrm{~nm}$ in diameter) might mimic the display in target pathogens (Ebola pseudotyped virus particles have $\sim 90 \mathrm{~nm}$ in diameter). Using a tag-and-modify ${ }^{27}$ strategy, we chose to selectively introduce a non-natural amino acid (tag) on the protein that could be used for the attachment (modify) of the selected glycodendrons appropriately functionalized at the focal position. As a stringent test of this approach we chose to mimic the highly glycosylated pathogen envelopes of Ebola virus. We selected a monomer $\mathrm{Q} \beta^{34,35}$ protein as carrier, which assembles into a 180 copy multimer. $\mathrm{Q} \beta$ multimer has been used by us and others to display glycans for other purposes but in these prior experiments only partial levels of nonspecific modification were achieved (see Supplementary Discussion). The result of these prior incomplete reactions was a formation of mixtures and not the desired homogeneous and (pseudo)symmetrical display required for this study ${ }^{36,37}$. This proteic platform provided the necessary viral mimic scaffold (core diameter, $\sim 28 \mathrm{~nm})^{34}$ to construct the desired multivalent systems.

The designed glycodendrons were prepared in a straightforward manner by the $\mathrm{Cu}(\mathrm{I})$-catalysed modification ${ }^{38,39}$ of the Huisgen cycloaddition as depicted in Fig. 2. $\alpha$-D-Mannose was chosen to be introduced onto the dendritic scaffolds as a relevant ligand that is recognized by DC-SIGN ${ }^{5}$. Synthesis of glycodendron 4 was accomplished using a modular strategy that advantageously avoided the need for carbohydrate protection. First, unprotected azidoethyl mannoside 3 (see Supplementary Methods) ${ }^{8}$ was coupled to the trialkynyl pentaerythritol core 2 using $\mathrm{CuSO}_{4}$ and sodium ascorbate in a 1:1 mixture of water:THF (tetrahydrofuran) at room temperature $(\mathrm{RT})^{40}$. The focal azido group required for subsequent site-specific conjugation to the protein tag, was introduced by reaction with sodium azide to give 5 . The designed modular strategy also allowed use of 5 in the construction of higher generation glycodendron $\mathbf{8}$. Thus, coupling of $\mathbf{5}$ with the trialkynyl core 6 gave 7 (Fig. 2), which was similarly converted to an azide $\mathbf{8}$ for protein modification.

Unnatural alkyne-containing amino acid L-homopropargylglycine (Hpg) was site-specifically introduced into the protein that would make up the proteic scaffold $(\mathrm{Q} \beta)$ to serve as an alkyne 'tag' through the expression of corresponding gene sequences in an auxotrophic strain of $E$. coli (B834(DE3) $)^{41}$. Gene sequences were designed to create a protein displaying alkyne at a site on the outer surface of the eventual icosahedral platform (Hpg16) for which the position could simply be controlled by the 'Met' triplet codon ATG. Replacement of wildtype methionine (Met) residues, with near-isosteric amino acid isoleucine allows reassignment of the codons in the gene sequence to allow incorporation instead of $\mathrm{Hpg}$ as a 'tag' (see Supplementary Methods for full details). The resulting $\mathrm{Q} \beta-(\mathrm{Hpg} 16)_{180}$ was characterized, including by mass spectrometry and dynamic light scattering (Fig. 3 and see Supplementary Methods and Supplementary Fig. S1), demonstrating the introduction of the Hpg amino acid into the sequence. On the basis of previous results $^{42,43}, \mathrm{Q} \beta-(\mathrm{Hpg} 16)_{180}$ was modified using a reaction mixture of $\mathrm{Cu}(\mathrm{I}) \mathrm{Br}$ complexed by tris[(1-ethylacetate- $1 H$-1,2,3-triazol-4-yl) methyl]amine in acetonitrile (Fig. 3a). It should be noted that the presence of $\mathrm{Hpg}$ on the protein results in slower Huisgen cycloaddition reaction rates in comparison with those obtained when azide in the form of azidohomoalanine (Aha) is present in the protein $^{42,43}$. Optimization of the reaction conditions by varying catalyst loading and stepwise addition, afforded the desired glycodendron-bearing virus-like particles. Thus, reaction of $\mathrm{Q} \beta$ $(\operatorname{Hpg} 16)_{180}$ with trivalent glycodendron 5 afforded Q $\beta$ - $\left(\mathrm{Man}_{3}\right)_{180}$ bearing 540 terminal mannosyl residues and reaction with secondgeneration nonavalent glycodendron 8 gave $\mathrm{Q} \beta-\left(\mathrm{Man}_{9}\right)_{180}$. Both reactions proceeded with $>95 \%$ conversion; consistent with greater bulk a longer reaction time (up to $7.5 \mathrm{~h}$ ) was required for reaction of 8 to form 1,620-mer $\mathrm{Q} \beta$ - $\left(\mathrm{Man}_{9}\right)_{180}$. Increasing particle diameter was observed, $\quad \mathrm{Q} \beta \quad(27.6 \mathrm{~nm}) \rightarrow \mathrm{Q} \beta-\left(\mathrm{Man}_{3}\right)_{180} \quad(29.8) \rightarrow \mathrm{Q} \beta$ $\left(\mathrm{Man}_{9}\right)_{180}$ (32.0), consistent with the controlled introduction of 'shells' of glycosylation $\sim 1.1 \mathrm{~nm}$ thick (Fig. $3 \mathrm{~b}$ and see Supplementary Table S1 for rough estimate of dendron length) 
a
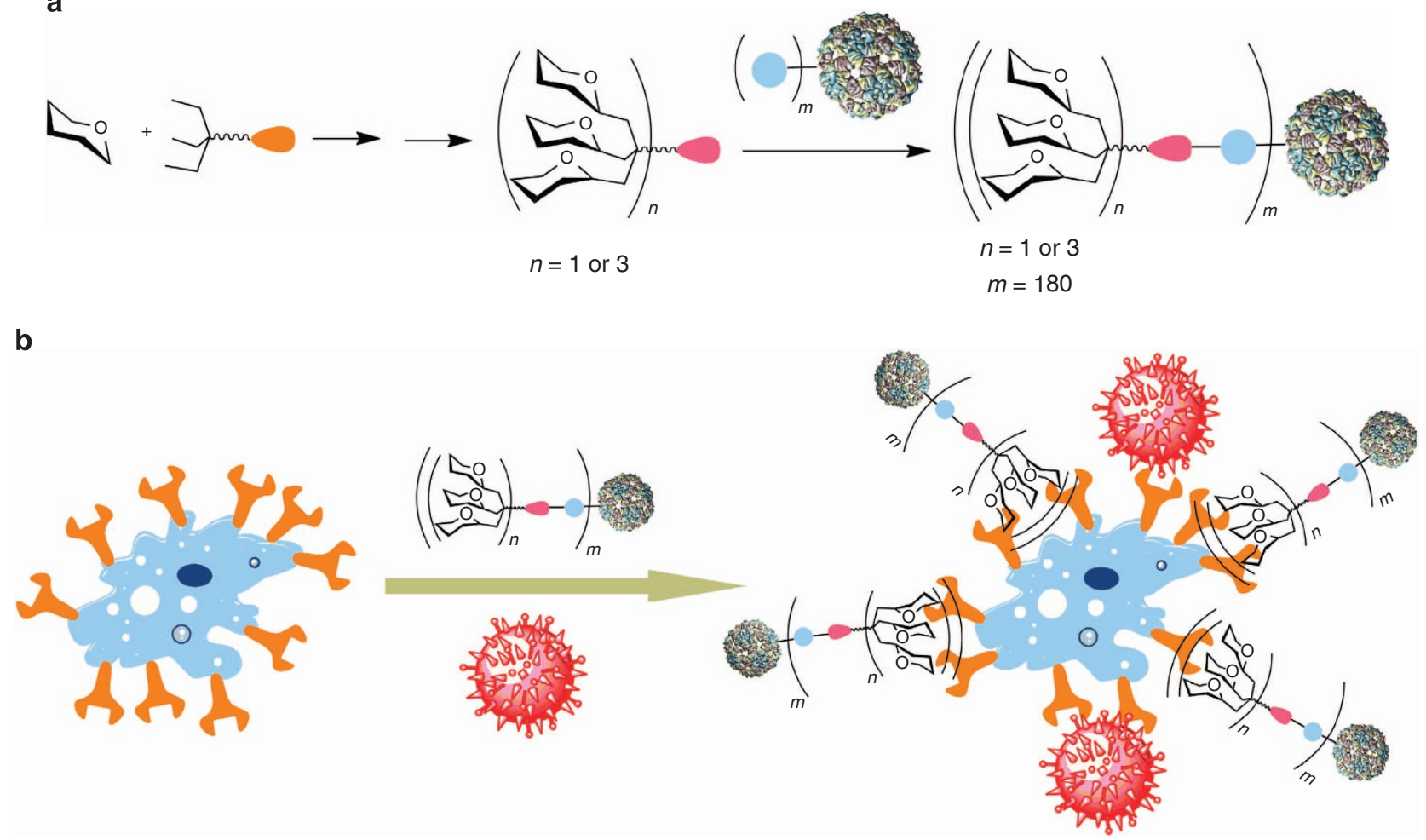

Figure 1 | Schematic representation of the nested polyvalency strategy. (a) Nested symmetrical assembly of virus-like glycodendrinanoparticles using a tag-and-modify strategy. Glycodendrons are created through iterative multivalent assembly and then attached to multiple tags, each in a monomer protein. (b) Ebola (shown in red) infection model and its competitive inhibition with virus-like glycodendrinanoparticles.

for each dendron generation. To the best of our knowledge, this is the first synthesis reported of such highly functionalized monodisperse glycodendriproteins (bearing up to 1,620 terminal sugar moieties) using a convergent approach.

Inhibition of DC-SIGN in vitro and on T lymphocytes. The inhibitory function of these glycodendriprotein particles was tested in several ways. Competition ELISA assay (See Supplementary Methods and Supplementary Figs S2 and S3) revealed that $\mathrm{Q} \beta$ - $\left(\mathrm{Man}_{3}\right)_{180}$ could completely inhibit the binding of DC-SIGN (as an Fc chimera) to a synthetically mannosylated glycoprotein (albumin bearing Man $\alpha 1-3$ (Man $\alpha 1-6)$ Man) with an estimated $\mathrm{IC}_{50} \sim 35-40 \mathrm{nM}$. A complete lack of inhibition by control, non-glycosylated $\mathrm{Q} \beta$ confirmed dependence of this promisingly potent inhibition upon glycan.

Next, an Ebola viral infection model $^{44}$, was explored using mammalian T-lymphocyte (Jurkat) cells displaying DC-SIGN. Recombinant viruses were produced in HEK 293 T cells; the viral construction was pseudotyped with Ebola virus envelope GP (EboGP) or the vesicular stomatitis virus envelope glycoprotein (VSV-G) and expressed luciferase as a reporter of the infection ${ }^{45}$. The inhibition of DC-SIGN-dependent infection of T-lymphocyte Jurkat cells (examined in at least three independent experiments) demonstrated that unglycosylated $\mathrm{Q} \beta$ reduced infection minimally (Fig. 4a). In contrast, $Q \beta-\left(\mathrm{Man}_{3}\right)_{180}$ and $\mathrm{Q} \beta-\left(\mathrm{Man}_{9}\right)_{180}$ showed strong dose-dependent inhibition of the infection process (Fig. $4 \mathrm{a}-$ c). Indeed, $\mathrm{Q} \beta-\left(\mathrm{Man}_{9}\right)_{180}$ presented a notable antiviral activity, inhibiting infection by $\sim 80 \%$ at $5 \mathrm{nM}$; estimated $\mathrm{IC}_{50} \mathrm{~s}=9.62 \mathrm{nM}$ for $\beta-\left(\operatorname{Man}_{3}\right)_{180}$ and $=910 \mathrm{pM}$ for $\mathrm{Q} \beta-\left(\mathrm{Man}_{9}\right)_{180}$.

VSV-G is able to infect T-lymphocyte Jurkat cells independently of DC-SIGN ${ }^{44}$ and provided a positive control in infection experiments; consistent with the proposed model of inhibition (Fig. 1) this glycan-independent pathway for VSV-G was completely uninhibited (Fig. 4b,c). In this model, the Ebola infection process is absolutely dependent on the presence of DCSIGN on the cell surface. Jurkat cells not expressing DC-SIGN were used as a negative control in the infection studies and showed no infection by Ebola pseudovirus (See Supplementary Fig. S4). The ratio of infection in cis between Jurkat DC-SIGN + and Jurkat cells was $\sim 2,600$ for Ebola virus infection and 0.96 for VSV infection.

Blocking of DC infection by pseudotyped Ebola. Having shown such potent inhibition of infection of a stable cell line that displays DC-SIGN, we next evaluated inhibition in the perhaps more relevant and more demanding context of inhibition of primary cells. DCs are a primary target of Ebola infection; these display multiple C-type lectins that could provide a different or modulated route for infection with potentially higher affinty for virus. Accordingly, DCs were generated from isolated human peripheral blood mononuclear cells (PBMCs) and tested. We were pleased to find that as for the stable Jurkat cell line presenting DC-SIGN alone, Q $\beta$ - $\left(\mathrm{Man}_{9}\right)_{180}$ displayed potent activity (Fig. 4d), inhibiting infection by $>80 \%$ at $5 \mathrm{nM}$ and $>95 \%$ at $25 \mathrm{nM}$ (estimated $\mathrm{IC}_{50}$ $\sim 2 \mathrm{nM}$ for $\left.\mathrm{Q} \beta-\left(\mathrm{Man}_{9}\right)_{180}\right)$. Excitingly, these data indicate that the mode of inhibition of these synthetic glycodendrinanoparticles translates into cellular contexts relevant to human infection and are consistent with the mode of action suggested in Fig. 1.

\section{Discussion}

Although the evaluation of the number of monomer units interacting during these inhibitory processes is complicated by quasi-equivalence $^{32}$, the data obtained indicate that these systems afford a clear polyvalency effect $(\beta)^{46}$ when compared with the 


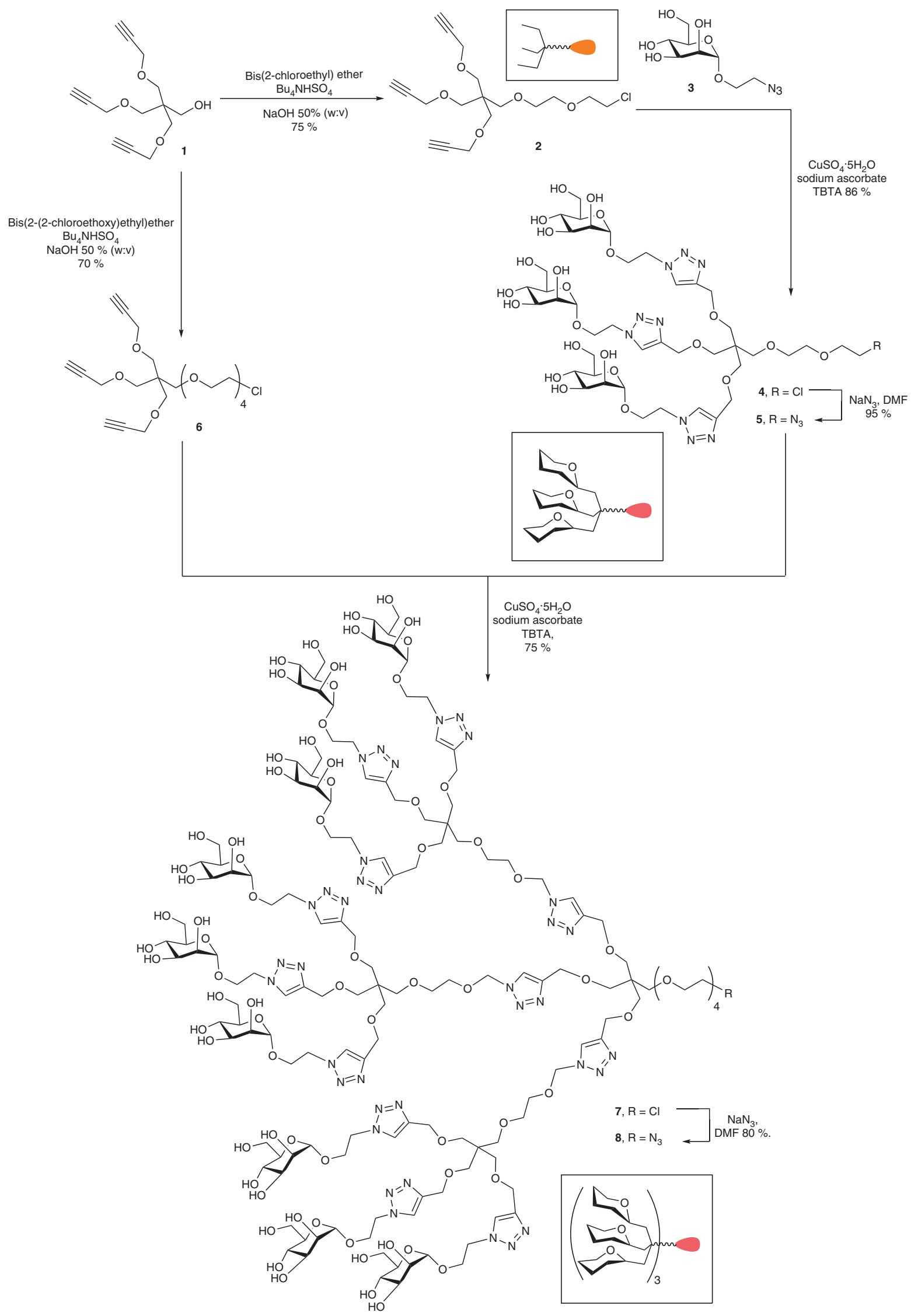

Figure $\mathbf{2}$ | Creation of polyvalent mannose-terminated glycodendrons. Synthesis of the glycondendron reagents $\mathbf{5}$ and $\mathbf{8}$ used in the assembly of virus-like glycodendri-nano-particles (see Fig. 3). TBTA, tribenzyl(tris)triazoylamine; DMF, N,N-dimethylformamide. 


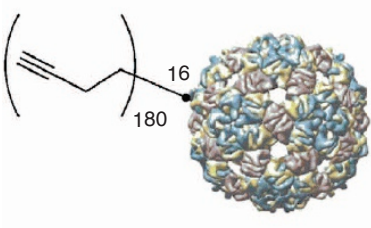

Qß-Hpg16 180

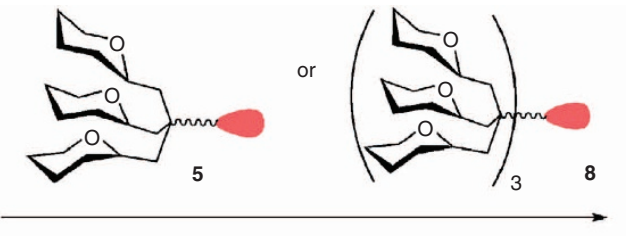

$\left(\sum_{\mathrm{N}}^{\mathrm{NaPi} \text { buffer }} 50 \mathrm{mM}, \mathrm{pH} 8\right.$

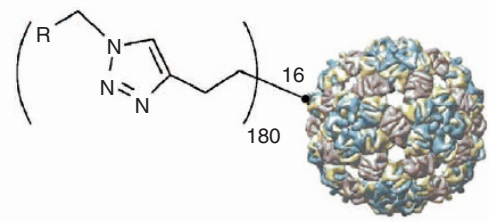

b
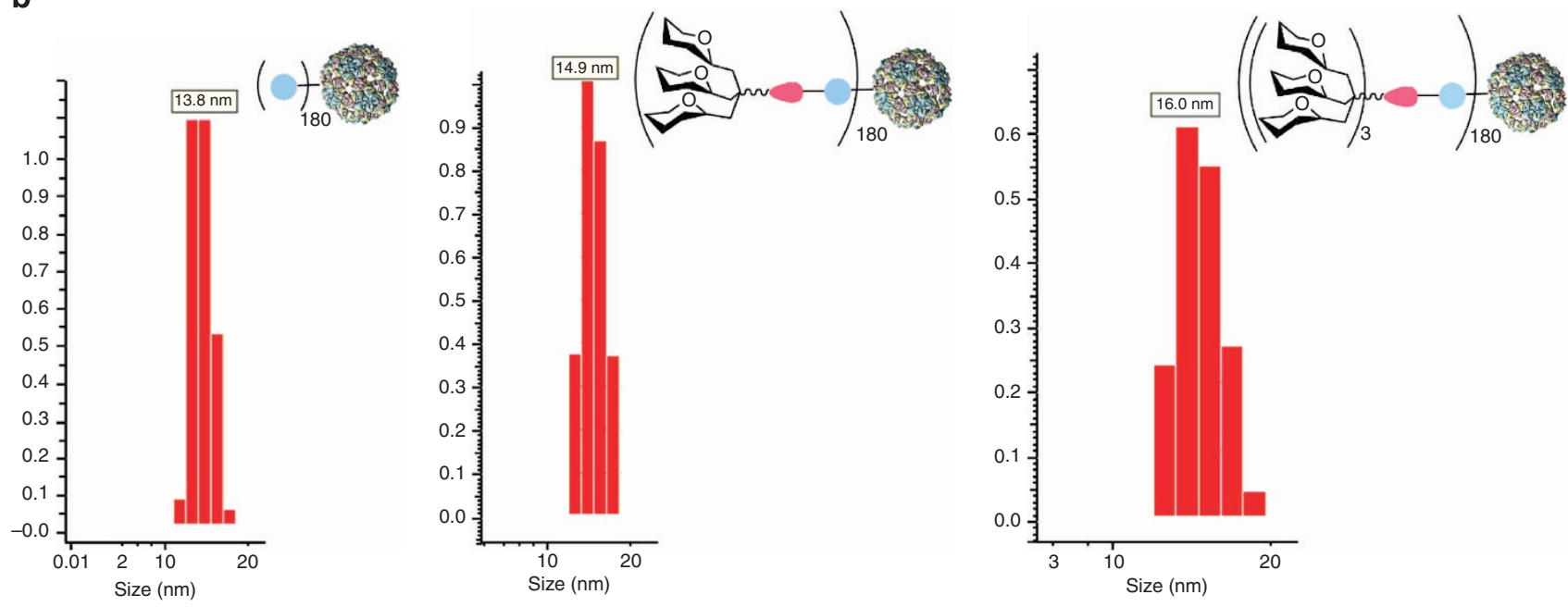

C
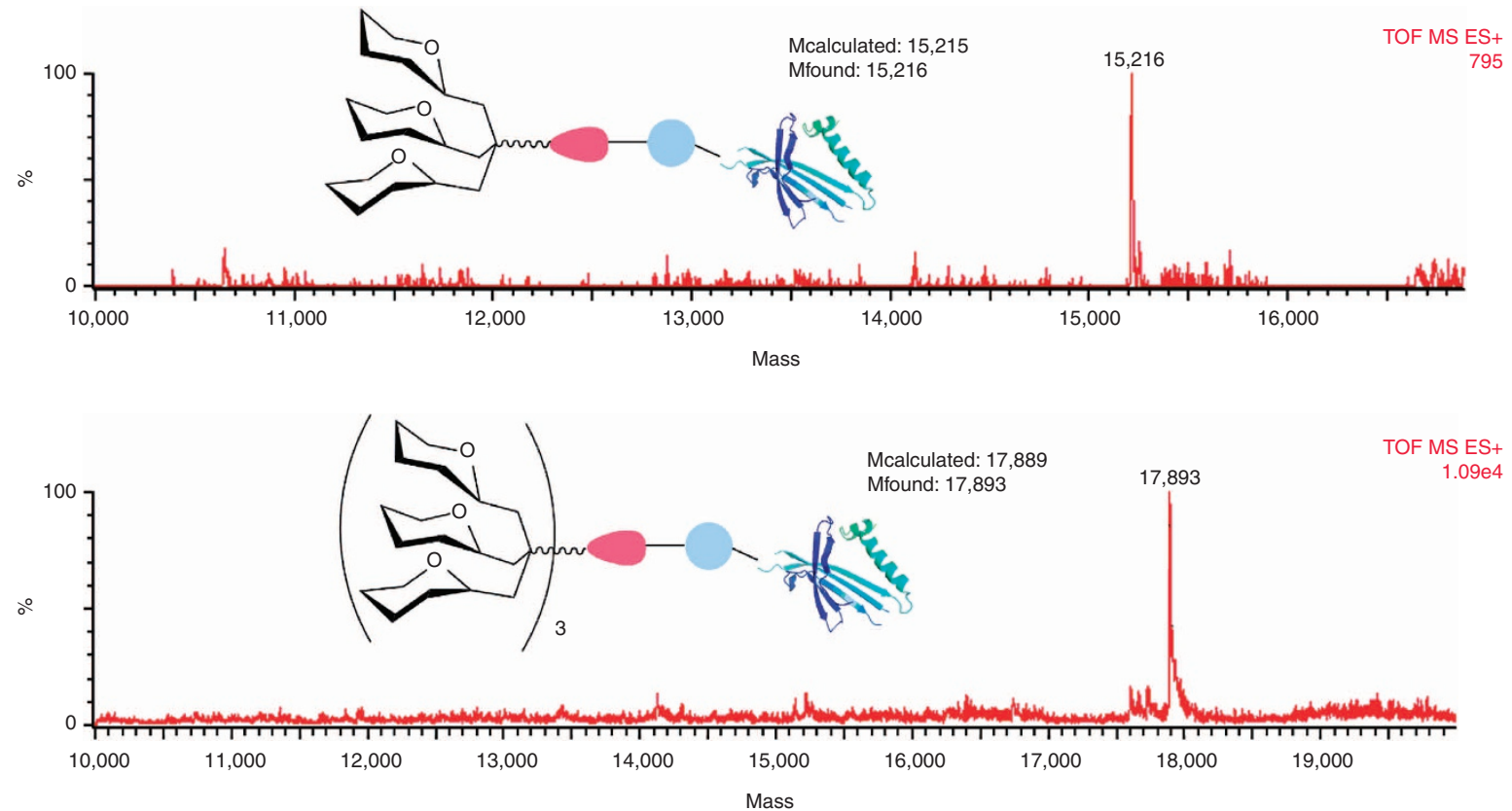

Figure 3 | Controlled assembly and characterization of virus-like glycodendri-nano-particles. (a) A tag-and-modify strategy allowed the generation of the second nested layer of multivalency from $\mathrm{Q} \beta-(\mathrm{Hpg} 16)_{180}$ using glycondendron reagents $\mathbf{5}$ and $\mathbf{8}$. R=corresponding glycodendron. (b) Dynamic light scattering histograms showing the hydrodynamic radius of $\mathrm{Q} \beta$ (radius $13.8 \mathrm{~nm}$ ), $\mathrm{Q} \beta$-(Man $\left.{ }_{3}\right)_{180}$ (radius 14.9) and $\mathrm{Q} \beta$-(Mang) 180 (radius 16.0). (c) Mass spectrometric analysis of monomer proteins of the particles. $\mathrm{P}_{\mathrm{i}}$, phosphate.

monomer methyl $\alpha$-D-mannopyranoside) (see Supplementary Table S2). The inhibitory properties of each mannoside monomer unit can therefore be considered ${ }^{46}$ to be $\sim 250$-fold and $\sim 860$ - fold (as judged by $\beta / \mathrm{N}$, see Supplementary Table S2) more potent when displayed in $\mathrm{Q} \beta\left(\mathrm{Man}_{3}\right)_{180}$ and $\mathrm{Q} \beta-\left(\mathrm{Man}_{9}\right)_{180}$, respectively, than when displayed alone. The efficiency of this system therefore 
a

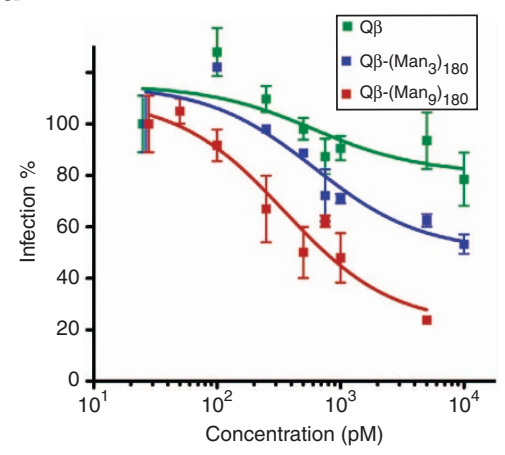

C

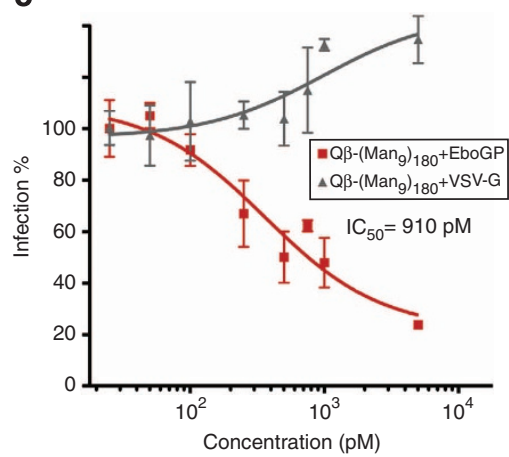

b

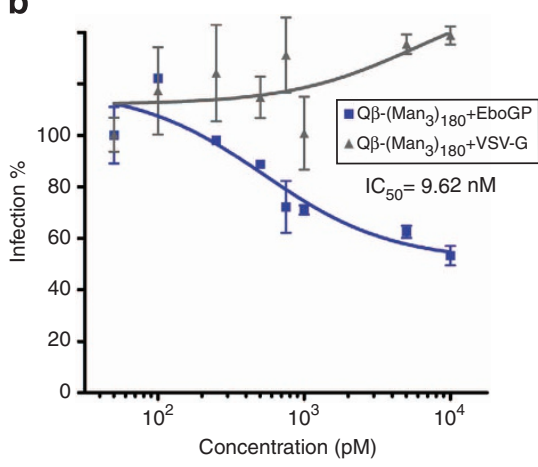

d

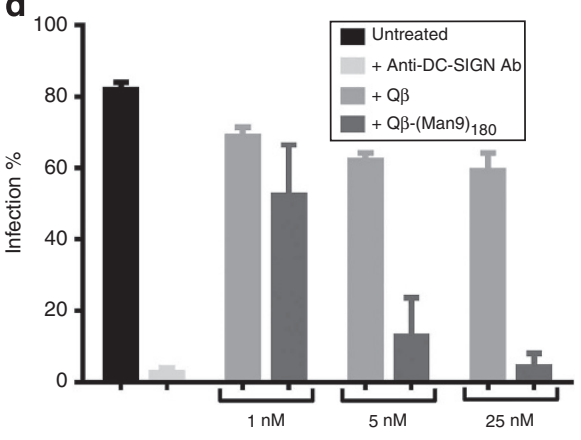

Figure 4 | Inhibition of viral infection of mammalian cells. (a) Comparison of infection rates of T-lymphocyte (Jurkat) cells displaying DC-SIGN by EboGP pseudovirus in the presence of $\mathrm{Q} \beta, \mathrm{Q} \beta-\left(\mathrm{Man}_{3}\right)_{180}, \mathrm{Q} \beta-\left(\mathrm{Man}_{9}\right)_{180}$; (b) Inhibition by $\mathrm{Q} \beta$ - $\left(\mathrm{Man}_{3}\right)_{180}$ of EBOV-GP (EboG) pseudovirus and vesicular stomatitis psuedovirus (VSV-G) in the infection (\% infection)of T-lymphocyte (Jurkat) cells displaying DC-SIGN; (c) as for (b) using Q $\beta$-(Man9) 180 . Values correspond to means of three experiments with s.e.m. shown; the $\mathrm{IC}_{50}$ s were estimated using Graphpad Prism v4.0 at $95 \%$ with a $95 \%$ confidence interval (4.43$20.9 \mathrm{nM}$ for $\mathrm{Q} \beta-\left(\mathrm{Man}_{3}\right)_{180}$ and $651 \mathrm{pM}-1.3 \mathrm{nM}$ for $\left.\mathrm{Q} \beta-\left(\mathrm{Man}_{9}\right)_{180}\right)$ and settings for normalized dose-response curves. See the Supplementary Fig. S5 for duplicated inhibition assays. (d) Inhibition of infection in cis of human DCs by EBOV-GP (EboG) using Q $\beta$-(Mang) 180 . Anti-DC-SIGN Ab is an antibody that blocks DC-SIGN. Immature DCs were generated from isolated human PBMCs. Blockade with anti-DC-sign antibody was used as a positive control.

relies upon a vital combination of not only a high number of displayed ligands but also display size and geometry. To date, no homogeneous polyvalent systems have been described that can generate such a large surface area (solvent-accessible surface area $\sim 725,000 \AA^{247}$ ) as the systems we have described here. The system we describe here is based on an icosahedral scaffold $(T=3$, triakis iscosahedral) that generates several underlying quasi-symmetry elements including those that relate the displayed glycodendrons in a two-fold, three-fold and six-fold manner (see Supplementary Movie 1). It is tempting to speculate that this, in turn, allows the simultaneous display of many distinct putative global glycan clusters where the glycan 'tips' are also quasi-equivalent (for example, 6-fold-related faces displaying a resultant 54-mer in $\mathrm{Q} \beta$ - $\left(\mathrm{Man}_{9}\right)_{180}$ or a 3-fold-related 9-mer in $\mathrm{Q} \beta$ - $\left(\mathrm{Man}_{3}\right)_{180}$, see Supplementary Movie 1). In this way, the nested glycan polyvalency that we have developed here may allow many subtly varying polyvalent combinations to be displayed, each of which (or even a combination of which) might give rise to optimal biological function (here inhibition of Ebola binding). These constructs are therefore not 'balls of sugar' but homogenous constructs that array varying faces with different polyvalent glycan arrangements. Thus, their most relevant structural features may well not be simply their average glycanto-glycan distance (as estimated, say, from $\mathrm{C} \alpha$-to- $\mathrm{C} \alpha$ residue distances of $\sim 28-40 \AA$ for 2-fold up to 6-fold quasi-symmetry) but instead the specific topology of glycan display and how that relates to both the inter-domain distances in the DC-SIGN tetramer ${ }^{48}$ as well as its organization on cell surfaces. ${ }^{49}$ Moreover, initial inspection of other viral surfaces suggests that such topologies might effectively out-compete not only Ebola but also other human pathogens. The striking $\beta$ values that we have discovered here may well arise from such specific 'optimal' faces (see Supplementary Movie 1 for illustrative examples of these quasi-symmetrical faces). Indeed, although direct comparison with non-viral systems is not possible, non-viral particles displaying multiple mannosyl residues in a less ordered manner are notably less potent and show much lower multivalency effects $(\beta \leq 20$, see Supplementary Table S2).

In summary, a novel nested polyvalency approach combined with tag-and-modify site-selective protein synthesis has allowed the creation of homogeneous protein platforms bearing glycodendrons. These well-defined polyvalent glycoprotein assemblies present on their surface up to 1,620 copies of glycan, a remarkably high valency never obtained before using a fully controlled strategy. These glycodendriprotein particles show exciting antiviral activity, preventing mammalian cell infection by Ebola pseudotyped virus through competitive blockade of the DC-SIGN receptor in the nanomolar to picomolar range. These results clearly indicate the efficiency of these systems to interact with this pattern recognition receptor and to compete with pathogens during their entry into target cells. Their in vivo activity remains to be tested and it is possible that such constructs, if used in this context, could elicit humoral responses that might potentially neutralize some of the interactions studied here. The high activity and fascinating (quasi)symmetric, high surface area morphology of these new glycoconjugates provides promising candidates for the development of both new antiviral agents as well as probes of larger-scale biological events. 


\section{Methods}

Synthesis of glycodendrons. Glycodendron 4: 2-Azidoethyl $\alpha$-D-mannopyranoside (306 mg, $1.2 \mathrm{mmol}$ ), 2-(2-chloroethoxy)ethoxymethyl trikis(2-propynyloxymethyl)methane (128 mg. $0.37 \mathrm{mmol}), \mathrm{CuSO}_{4} \cdot 5 \mathrm{H}_{2} \mathrm{O}(9 \mathrm{mg}, 0.04 \mathrm{mmol})$, tribenzyl(tris)triazoylamine $(39 \mathrm{mg}, 0.07 \mathrm{mmol})$ and sodium ascorbate $(29 \mathrm{mg}$, $0.15 \mathrm{mmol}$ ) were dissolved in $2 \mathrm{ml}$ of $\mathrm{THF} / \mathrm{H}_{2} \mathrm{O}(1: 1)$. After consumption of the starting material $(3 \mathrm{~h})$, the solvent was evaporated and the crude was purified by size-exclusion chromatography (Sephadex LH-20 MeOH 100\%), furnishing the glycondendron 4 as a white foam $(347 \mathrm{mg}, 86 \%)$.

Glycodendron 5: Glycodendron $4(80 \mathrm{mg}, 0.07 \mathrm{mmol})$ and sodium azide $(47 \mathrm{mg}$, $0.7 \mathrm{mmol}$ ) were dissolved in $\mathrm{N}, \mathrm{N}$-dimethylformamide $(2 \mathrm{ml})$. The mixture was stirred at $60{ }^{\circ} \mathrm{C}$ for 4 days. After consumption of the starting material, the solvent was concentrated and the crude was purified by size-exclusion chromatography (Sephadex G-25 $\mathrm{H}_{2} \mathrm{O} / \mathrm{MeOH}$ 9:1), furnishing glycondendron 5 (76 mg, 95\%) as a white foam.

Glycodendron 7: Glycodendron 5 (30 mg, $0.03 \mathrm{mmol}$ ), [2-[2-(2-chloroethoxy)ethoxy] ethoxy] ethoxymethyl tris(2-propynyloxymethyl)methane $(3.6 \mathrm{mg}$, $0.008 \mathrm{mmol}), \mathrm{CuSO}_{4} \cdot 5 \mathrm{H}_{2} \mathrm{O}(0.5 \mathrm{mg}, 0.002 \mathrm{mmol})$, tribenzyl(tris)triazoylamine $(1.7 \mathrm{mg}, 0.003 \mathrm{mmol})$ and sodium ascorbate $(1.3 \mathrm{mg}, 0.006 \mathrm{mmol})$ were dissolved in $\mathrm{THF} / \mathrm{H}_{2} \mathrm{O}(1: 1,1 \mathrm{ml})$. After consumption of the starting material, the solvent was evaporated and the crude was purified by size-exclusion chromatography (Sephadex LH-20 MeOH 100\%), furnishing glycondendron 7 (22 mg, 75\%) as a white foam.

Glycodendron 8: Glycodendron $7(25 \mathrm{mg}, 0.007 \mathrm{mmol})$ and sodium azide $(4 \mathrm{mg}$, $0.07 \mathrm{mmol}$ ) were dissolved in $\mathrm{N}, \mathrm{N}$-dimethylformamide $(1 \mathrm{ml})$. The mixture was stirred at $60^{\circ} \mathrm{C}$ for 4 days. After that, the solvent was concentrated and the crude was purified by size-exclusion chromatography (Sephadex G-25 $\mathrm{H}_{2} \mathrm{O} / \mathrm{MeOH} 9: 1$ ), furnishing glycondendron $8(20 \mathrm{mg}, 80 \%)$ as a white foam.

Synthesis of virus-like glycodendrinanoparticles. Glycoprotein $Q \beta-\left(\mathrm{Man}_{3}\right)_{180}$ : Glycodendron 5 ( $2.84 \mathrm{mg}, 0.002 \mathrm{mmol})$ was dissolved in sodium phosphate buffer $(50 \mathrm{mM}, \mathrm{pH}=8,200 \mu \mathrm{l})$. Protein solution $(180 \mu \mathrm{g}, 100 \mu \mathrm{l})$ was added to the above solution and mixed thoroughly. A freshly prepared solution of copper (I) bromide $(99.999 \%)$ in acetonitrile $\left(32.6 \mu \mathrm{lof} 10 \mathrm{mg} \mathrm{ml}^{-1}\right)$ was premixed with an acetonitrile solution of tris[(1-ethylacetate-1H-1,2,3- triazol-4-yl)methyl] amine $(12.6 \mu \mathrm{l}$ of $\left.100 \mathrm{mg} \mathrm{ml}^{-1}\right)$. The preformed Cu-complex solution $(25 \mu \mathrm{l})$ was added to the mixture and the reaction was agitated on a rotator for at RT. After $4 \mathrm{~h}, 150 \mu \mathrm{l}$ of buffer and $50 \mu \mathrm{l}$ of fresh $\mathrm{Cu}$-complex solution were added to the mixture again and the reaction was agitated for a further $1.5 \mathrm{~h}$. The resulting mixture was purified in PD-MiniTrap (G-25) twice and concentrated on a vivaspin membrane concentrator $(30 \mathrm{KDa}$ molecular weight cut off) to $400 \mu \mathrm{l}$. To a virus-like particle aliquot $(20 \mu \mathrm{l})$ was added $1 \mu \mathrm{l}$ of TCEP $(1 \mathrm{M})$ to allow the protein to denature before analysis by liquid chromatography-mass spectrometry. Electrospray Ionization Mass Spectrometry (TOF ES + ) $(\mathrm{m} / \mathrm{z}$ ): calc. 15,215; found 15,216.

Glycoprotein $Q \beta$ - $\left(\mathrm{Man}_{9}\right)_{180}$ : Glycodendron 8 (4.8 $\left.\mathrm{mg}, 0.001 \mathrm{mmol}\right)$ was dissolved in sodium phosphate buffer $(50 \mathrm{mM}, \mathrm{pH}=8,50 \mu \mathrm{l})$. Protein solution $(90 \mu \mathrm{g}, 50 \mu \mathrm{l})$ was added to the above solution and mixed thoroughly. A freshly prepared solution of copper (I) bromide (99.999\%) in acetonitrile $\left(32.6 \mu \mathrm{l}\right.$ of $\left.10 \mathrm{mg} \mathrm{ml}^{-1}\right)$ was premixed with an acetonitrile solution tris[(1-ethylacetate- $1 \mathrm{H}-1,2,3$ - triazol-4-yl)methyl] amine, $\left(12.6 \mu \mathrm{l}\right.$ of $\left.100 \mathrm{mg} \mathrm{ml}^{-1}\right)$. The preformed Cu-complex solution $(25 \mu \mathrm{l})$ was added to the mixture and the reaction was agitated on a rotator at RT. After 3 and $6 \mathrm{~h}, 50 \mu \mathrm{l}$ of buffer and $12.5 \mu \mathrm{l}$ of fresh Cu-complex solution were added to the mixture again (each time) and the reaction was agitated for further $1.5 \mathrm{~h}$. The resulting mixture was purified in PD-MiniTrap (G-25) twice and concentrated on a vivaspin membrane concentrator ( $30 \mathrm{KDa}$ molecular weight cut off) to $400 \mu \mathrm{l}$. To a virus-like particle aliquot $(20 \mu \mathrm{l})$ was added $1 \mu \mathrm{l}$ of TCEP (1M) to allow the protein to denature before analysis by liquid chromatography-mass spectrometry. ESI-MS $($ TOF ES +$)(m / z)$ : calc. 17,889 ; found 17,893

Production of recombinant viruses. Recombinant viruses were produced in 293T cells. The viral construction was pseudotyped with EboGP or VSV-G and expressed luciferase as a reporter of the infection ${ }^{45}$. One day $(18-24 \mathrm{~h})$ before transfection, $6 \times 10^{6} 293 \mathrm{~T}$ were seeded onto $10 \mathrm{~cm}$ plates. Cells were cultured in DMEM medium supplemented with $10 \%$ heat-inactivated FBS, $25 \mathrm{mg}$ gentamycin, $2 \mathrm{mM}$ L-glutamine. A few minutes before transfection, the medium on transfection plates was changed to $9 \mathrm{ml}$ DMEM and chloroquine was added to $25 \mu \mathrm{M}$ final concentration. Transfection reaction with all reagents at RT was prepared in $15 \mathrm{ml}$ tubes: $183 \mu \mathrm{l}$ of $2 \mathrm{M} \mathrm{CaCl}_{2}$, $450 \mathrm{ng}$ of Ebola virus envelope, $21 \mu \mathrm{g}$ of pNL4-3 luc ${ }^{50}, 1,300 \mu \mathrm{l}$ of water. Next, $1.5 \mathrm{~m}$ of 2 xHBS (hepes buffer saline) $\mathrm{pH} 7.0$ was added quickly to the tubes and bubbled for $30 \mathrm{~s}$. HBS/DNA solution was gently dropped onto medium. After $8 \mathrm{~h}$ of incubation at $37^{\circ} \mathrm{C}$ with $5 \% \mathrm{CO}_{2}$, medium on transfection plates was changed to $10 \mathrm{ml} \mathrm{DMEM}$ and once again 1 day after transfection to $7 \mathrm{ml} \mathrm{DMEM}$. Transfection supernatants were collected after $48 \mathrm{~h}$, centrifuged at $1,200 \mathrm{rpm}$ for $10 \mathrm{~min}$ at RT to remove cell debris, and stored frozen at $-80^{\circ} \mathrm{C}$ (ref. 51).

Infection of Jurkat cells displaying DC-SIGN in cis. Infection was performed on Jurkat cells (T-lymphocyte cell line) expressing receptor DC-SIGN on their surface. One day before infection, $5 \times 10^{4}$ of Jurkat DC-SIGN cells were plated into each well of 96-well plate. Cells were incubated at RT for $20 \mathrm{~min}$ with the carbohydratebased compounds and then challenged with 5000 Tissue Culture Infective Dose of recombinant viruses. After $48 \mathrm{~h}$ of incubation cells were washed twice with PBS and lysed for luciferase assay. The range of concentrations tested for compounds $Q \beta$ and $\mathrm{Q} \beta-\left(\mathrm{Man}_{3}\right)_{180}$ was $100 \mathrm{pM}-50 \mathrm{nM}$ and for compound $\mathrm{Q} \beta-\left(\mathrm{Man}_{9}\right)_{180}$ was $50 \mathrm{pM}-50 \mathrm{nM}$. As a control, an experiment of infection with VSV-G pseudoviruses was performed under the same conditions. Infection with VSV-G is independent of the presence of DC-SIGN receptor.

Generation of monocyte-derived DCs (DCs). PBMCs were isolated from buffy coats from healthy human donors (Hospital 12 de Octubre, Madrid, Spain) by Ficoll-Paque (Pharmacia, Uppsala, Sweden) density-gradient centrifugation. Following the centrifugation of $40 \mathrm{ml}$ of whole blood samples on Ficoll-Paque at $2,000 \mathrm{rpm}$ for $30 \mathrm{~min}$, the cells from interface were collected and washed five times with PBS at 1,500 rpm for $5 \mathrm{~min}$ at RT. PBMCs were then resuspended in RPMI medium supplemented with $10 \%$ heat-inactivated FBS, $25 \mathrm{mg}$ gentamycin, $2 \mathrm{mM}$ L-glutamine at concentration $2 \times 10^{6}$ cells per ml and placed onto 24 -well plate for $1 \mathrm{~h}$ at $37^{\circ} \mathrm{C}$ with $5 \% \mathrm{CO}_{2}$. The adherent monolayer of monocytes were then washed twice with PBS and resuspended in RPMI medium supplemented with cytokines granulocyte-macrophage colony-stimulating factor $\left(200 \mathrm{ng} \mathrm{ml}^{-1}\right)$ and IL-4 $\left(10 \mathrm{ng} \mathrm{ml}^{-1}\right)$. For the differentiation of immature monocyte-derived DCs, cells were incubated at $37{ }^{\circ} \mathrm{C}$ with $5 \% \mathrm{CO}_{2}$ for 7 days and subsequently activated with cytokines on day 2 and 5 (refs 44,52,53).

Infection of immature monocyte-derived DCs in cis. Immature monocytederived DCs were incubated at RT for 20 min with the carbohydrate-based compounds and then challenged with 5000 TCID of EBOV-GP recombinant pseudoviruses. After $48 \mathrm{~h}$ of incubation cells were washed twice with PBS and lysed for luciferase assay. The range of concentrations tested for Q $\beta$ - $\left(\mathrm{Man}_{9}\right)_{180}$ was 1,5 and $25 \mathrm{nM}$. As a control, experiment of inhibition of infection of EBOV-GP was performed in the presence of antibody anti-DC-SIGN and mannan at concentration of $25 \mu \mathrm{g} \mathrm{ml}^{-1}$.

Statistical methods. Dynamic light scattering: Dynamic light scattering values represent the average of 10 independent measurements, where 10 individual acquisitions were taken per measurement the results analysed using OmniSIZE software.

Infection assays: Statistical analysis was performed using GraphPad Prism v6.0. Infection of mammalian Jurkat cells displaying DC-SIGN by EboV-GP pseudotyped viruses: The values of percentage of infection presented on the graph correspond to the mean of six independent experiments with error bars corresponding to the s.e.m. The $\mathrm{IC}_{50}$ values were estimated using GraphPad Prism v6.0 with a 95\% confidence interval and settings to normalize dose-response curves.

Infection of primary monocyte-derived DC by EboV-GP pseudotyped viruses: The values of percentage of infection correspond to the mean of two independent experiments (error bars describe the range between the two values obtained)

\section{References}

1. Neyrolles, O., Gicquel, B. \& Quintana-Murci, L. Towards a crucial role for DCSIGN in tuberculosis and beyond. Trends Microbiol. 14, 383-387 (2006).

2. Gordon, S. Pattern recognition receptors: doubling up for the innate immune response. Cell 111, 927-930 (2002).

3. Medzhitov, R. Recognition of microorganisms and activation of the immune response. Nature 449, 819-826 (2007).

4. Geijtenbeek, T. B. H. et al. Identification of DC-SIGN, a novel dendritic cell specific ICAM-3 receptor that supports primary immune responses. Cell 100, 575-585 (2000)

5. Guo, Y. et al. Structural basis for distinct ligand-binding and targeting properties of the receptors DC-SIGN and DC-SIGNR. Nat. Struct. Mol. Biol. 11, 591-598 (2004).

6. Steinman, R. M. DC-SIGN: a guide to some mysteries of dendritic cells. Cell 100, 491-494 (2000)

7. van, K. Y. \& Geijtenbeek, T. B. H. DC-SIGN: escape mechanism for pathogens Nat. Rev. Immunol. 3, 697-709 (2003)

8. Arce, E. et al. Glycodendritic structures based on Boltorn hyperbranched polymers and their interactions with Lens culinaris lectin. Bioconjugate Chem. 14, 817-823 (2003).

9. Lasala, F., Arce, E., Otero, J. R., Rojo, J. \& Delgado, R. Mannosyl glycodendritic structure inhibits DC-SIGN-mediated ebola virus infection in cis and in trans. Antimicrob. Agents Chemother. 47, 3970-3972 (2003).

10. Borrok, M. J. \& Kiessling, L. L. Non-carbohydrate inhibitors of the lectin DCSIGN. J. Am. Chem. Soc. 129, 12780-12785 (2007).

11. Reina, J. J. et al. 1,2-Mannobioside mimic: synthesis, DC-SIGN interaction by NMR and docking, and antiviral activity. ChemMedChem 2, 1030-1036 (2007).

12. Mitchell, D. A. et al. Synthesis 2-C-branched derivatives of D-mannose: 2-C aminomethyl-D-mannose binds to the human C-type lectin DC-SIGN with affinity greater than an order of magnitude compared to that of D-mannose. Tetrahedron Asymmetry 18, 1502-1510 (2007). 
13. Martínez-Ávila, O. et al. Multivalent manno-glyconanoparticles inhibit DCSIGN-mediated HIV-1 trans-infection of human T cells. ChemBioChem 10, 1806-1809 (2009).

14. Martínez-Ávila, O. et al. Gold manno-glyconanoparticles: multivalent systems to block HIV-1 gp120 binding to the lectin DC-SIGN. Chem. Eur. J. 15, 9874-9888 (2009).

15. Sattin, S. et al. Inhibition of DC-SIGN-mediated HIV infection by a linear trimannoside mimic in a tetravalent presentation. ACS Chem. Biol. 5, 301-312 (2010)

16. Sanchez-Navarro, M. \& Rojo, J. Targeting DC-SIGN wih carbohydrate multivalent systems. Drug News Perspect. 23, 557-572 (2010).

17. Wang, S.-K. et al. Targeting the carbohydrates on HIV-1: interaction of oligomannose dendrons with human monoclonal antibody $2 \mathrm{G} 12$ and DC-SIGN. Proc. Natl Acad. Sci. USA 105, 3690-3695 (2008).

18. Greatrex, B. W. et al. The synthesis and immune stimulating action of mannose-capped lysine-based dendrimers. Tetrahedron 65, 2939-2950 (2009).

19. Luczkowiak, J. et al. Pseudosaccharide functionalized dendrimers as potent inhibitors of DC-SIGN dependent Ebola pseudotyped viral infection. Bioconjugate Chem. 22, 1354-1365 (2011).

20. Andreini, M. et al. Second generation of fucose-based DC-SIGN ligands: affinity improvement and specificity versus Langerin. Org. Biomol. Chem. 9, 5778-5786 (2011).

21. Prost, L. R., Grim, J. C., Tonelli, M. \& Kiessling, L. L. Noncarbohydrate glycomimetics and glycoprotein surrogates as DC-SIGN antagonists and agonists. ACS Chem. Biol. 7, 1603-1608 (2012).

22. André, S., Ortega, P. J. C., Perez, M. A., Roy, R. \& Gabius, H.-J. Lactose containing starburst dendrimers: influence of dendrimer generation and binding-site orientation of receptors (plant/animal lectins and immunoglobulins) on binding properties. Glycobiology 9, 1253-1261 (1999).

23. Camponovo, J. et al. 'Click' glycodendrimers containing 27, 81, and 243 modified xylopyranoside termini. J. Org. Chem. 74, 5071-5074 (2009).

24. Davis, B. G. The controlled glycosylation of a protein with a bivalent glycan: towards a new class of glycoconjugates, glycodendriproteins. Chem. Commun. 351-352 (2001)

25. Rendle, P. M. et al. Glycodendriproteins: a synthetic glycoprotein mimic enzyme with branched sugar-display potently inhibits bacterial aggregation. J. Am. Chem. Soc. 126, 4750-4751 (2004).

26. Robinson, M. A. et al. LEAPT: lectin-directed enzyme-activated prodrug therapy. Proc. Natl Acad. Sci. USA 101, 14527-14532 (2004).

27. Chalker, J. M., Bernardes, G. J. L. \& Davis, B. G. A 'tag-and-modify' approach to site-selective protein modification. Acc. Chem. Res. 44, 730-741 (2011).

28. Sato, M. et al. Glycoinsulins: dendritic sialyloligosaccharide-displaying insulins showing a prolonged blood-sugar-lowering activity. J. Am. Chem. Soc. 126, 14013-14022 (2004).

29. Ni, J., Song, H., Wang, Y., Stamatos, N. M. \& Wang, L. -X. Toward a carbohydrate-based HIV-1 vaccine: synthesis and immunological studies of oligomannose-containing glycoconjugates. Bioconjugate Chem. 17, 493-500 (2006).

30. Kostiainen, M. A., Szilvay, G. R., Smith, D. K., Linder, M. B. \& Ikkala, O. Multivalent dendrons for high-affinity adhesion of proteins to DNA. Angew. Chem. Int. Ed. 45, 3538-3542 (2006).

31. Crick, F. H. C. \& Watson, J. D. The structure of small viruses. Nature 177, 473-475 (1956)

32. Caspar, D. L. D. \& Klug, A. Physical principles in the construction of regular viruses. Cold Spring Harbor Symp. Quant. Biol. 27, 1-24 (1962).

33. Johnson, J. E. \& Speir, J. A. Quasi-equivalent viruses: a paradigm for protein assemblies. J. Mol. Biol. 269, 665-675 (1997).

34. Kozlovska, T. M. et al. Recombinant RNA phage Q $\beta$ capsid particles synthesized and self-assembled in Escherichia coli. Gene 137, 133-137 (1993).

35. Strable, E. et al. Unnatural amino acid incorporation into virus-like particles. Bioconjugate Chem. 19, 866-875 (2008).

36. Astronomo, R. et al. Defining criteria for oligomannose immunogens for HIV using icosahedral virus capsid scaffolds. Chem. Biol. 17, 357-370 (2010).

37. Doores, K. J. et al. A nonself sugar mimic of the HIV glycan shield shows enhanced antigenicity. Proc. Natl Acad. Sci. USA 107, 17107-17112 (2010).

38. Tornøe, C. W., Christensen, C. \& Meldal, M. Peptidotriazoles on solid phase: $[1,2,3]$-triazoles by regiospecific copper(I)-catalyzed 1,3-dipolar cycloadditions of terminal alkynes to azides. J. Org. Chem. 67, 3057-3064 (2002).

39. Rostovtsev, V. V., Green, L. G., Fokin, V. V. \& Sharpless, K. B. A stepwise huisgen cycloaddition process: copper(I)-catalyzed regioselective 'ligation' of azides and terminal alkynes. Angew. Chem. Int. Ed. 41, 2596-2599 (2002).

40. Ortega-Muñoz, M., Lopez-Jaramillo, J., Hernandez-Mateo, F. \& SantoyoGonzalez, F. Synthesis of glyco-silicas by $\mathrm{Cu}(\mathrm{I})$-catalyzed 'click-chemistry' and their applications in affinity chromatography. Adv. Synth. Catal. 348, 2410-2420 (2006)

41. Van, H. J. C. M., Kiick, K. L. \& Tirrell, D. A. Efficient incorporation of unsaturated methionine analogues into proteins in vivo. J. Am. Chem. Soc. 122 1282-1288 (2000).

42. van Kasteren, S. I., Kramer, H. B., Gamblin, D. P. \& Davis, B. G. Siteselective glycosylation of proteins: creating synthetic glycoproteins. Nat. Protoc. 2, 3185-3194 (2007).

43. van Kasteren, S. I. et al. Expanding the diversity of chemical protein modification allows post-translational mimicry. Nature 446, 1105-1109 (2007).

44. Alvarez, C. P. et al. C-type lectins DC-SIGN and L-SIGN mediate cellular entry by Ebola virus in cis and in trans. J. Virol. 76, 6841-6844 (2002).

45. Yang, Z.-y. et al. Distinct cellular interactions of secreted and transmembrane Ebola virus glycoproteins. Science 279, 1034-1037 (1998).

46. Mammen, M., Choi, S.-K. \& Whitesides, G. M. Polyvalent interactions in biological systems: implications for design and use of multivalent ligands and inhibitors. Angew. Chem. Int. Ed. 37 (1998).

47. Golmohammadi, R., Fridborg, K., Bundule, M., Valegard, K. \& Liljas, L. The crystal structure of bacteriophage Q beta at 3.5 A resolution. Structure 4, 543 (1996)

48. Tabarani, G. et al. DC-SIGN neck domain is a $\mathrm{pH}$-sensor controlling oligomerization. J. Biol. Chem. 284, 21229-21240 (2009)

49. de Bakker, B. I. et al. Nanoscale organization of the pathogen receptor DCSIGN mapped by single-molecule high-resolution fluorescence microscopy. ChemPhysChem 8, 1473-1480 (2007).

50. He, J. et al. Human immunodeficiency virus type 1 viral protein R (Vpr) arrests cells in the G2 phase of the cell cycle by inhibiting p34cdc2 activity. J. Virol. 69, 6705-6711 (1995).

51. Yang, S. et al. Generation of retroviral vector for clinical studies using transient transfection. Hum. Gene Ther. 10, 123-132 (1999).

52. Puig-Kroger, A. et al. Maturation-dependent expression and function of the CD49d integrin on monocyte-derived human dendritic cells. J. Immunol. 165, 4338-4345 (2000).

53. Relloso, M. et al. DC-SIGN (CD209) expression is IL-4 dependent and is negatively regulated by IFN, TGF- $\beta$, and anti-inflammatory agents. J. Immunol. 168, 2634-2643 (2002)

\section{Acknowledgements}

We acknowledge the financial support by the MICINN of Spain CTQ2008-01694 and CTQ2011-23410, the EU RTN CARMUSYS (PITN-GA-2008-213592), Instituto de Salud Carlos III (FIS PI080806 and PI1101580) and Fundación para la Investigación y Prevención del SIDA (FIPSE 36749) and the European FEDER funds. We thank Professors A. Sánchez (Centers for Disease Control and Prevention, Atlanta, GA) and M.G. Finn (TSRI, La Jolla, CA) for providing Zaire Ebola Virus glycoprotein and p75m/Q $\beta$ plasmids, respectively. MSN thanks Fundación Ramón Areces for funding, BGD is a Royal Society Wolfson Research Merit Award recipient and is supported by an EPSRC LSI Platform grant.

\section{Author contributions}

R.R.-V. and M.S.N. synthesized the glycodendrons and the glycodendriproteins, J.L. carried out the Ebola infection experiments. J.R.K. expressed and purified Q $\beta$. M.S.N., R.D., J.R. and B.G.D. designed the experiments. All the authors discussed results and analysed the data. M.S.N. and B.G.D. wrote the manuscript. Correspondence and requests for materials should be addressed to R.D., J.R. and B.G.D.

\section{Additional information}

Supplementary Information accompanies this paper at http://www.nature.com/ naturecommunications

Competing financial interests: The authors declare no competing financial interests.

Reprints and permission information is available online at http://npg.nature.com/ reprintsandpermissions/

How to cite this article: Ribeiro-Viana, R. et al. Virus-like glycodendrinanoparticles displaying quasi-equivalent nested polyvalency upon glycoprotein platforms potently block viral infection. Nat. Commun. 3:1303 doi: 10.1038/ncomms2302 (2012).

This work is licensed under a Creative Commons AttributionNonCommercial-NoDerivs 3.0 Unported License. To view a copy of this license, visit http://creativecommons.org/licenses/by-nc-nd/3.0/ 
Erratum: Virus-like glycodendrinanoparticles displaying quasi-equivalent nested polyvalency upon glycoprotein platforms potently block viral infection

Renato Ribeiro-Viana, Macarena Sánchez-Navarro, Joanna Luczkowiak, Julia R. Koeppe, Rafael Delgado, Javier Rojo \& Benjamin G. Davis

Nature Communications 3:1303 doi: 10.1038/ncomms2302 (2012); Published 18 Dec 2012; Updated 5 Feb 2013

During the production of this Article, the $y$ axis of the bar chart in Fig. $4 \mathrm{~d}$ was mislabelled. The correct version of Fig. 4 appears below.

a

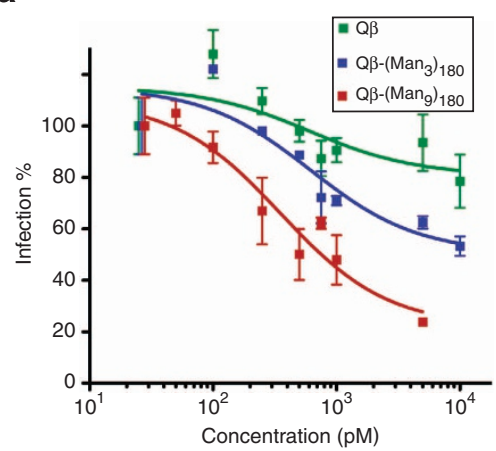

C

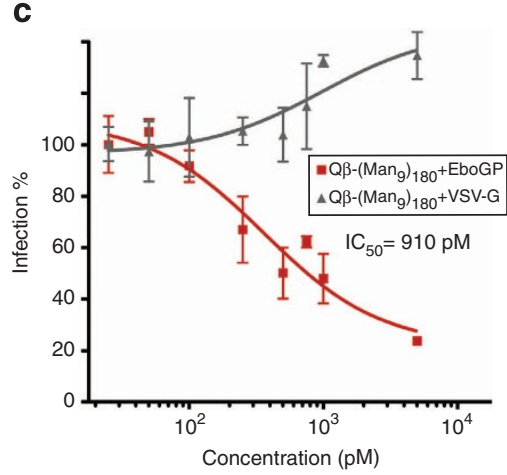

b

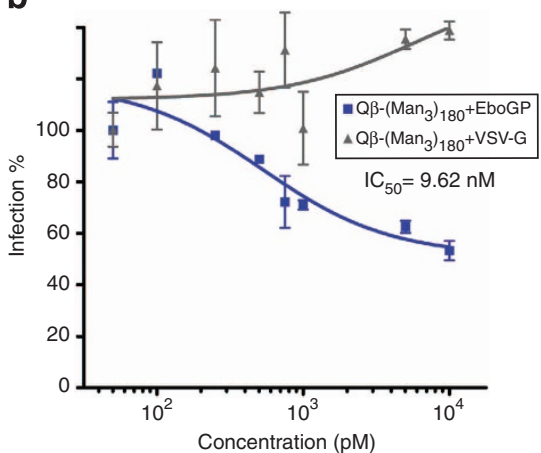

d

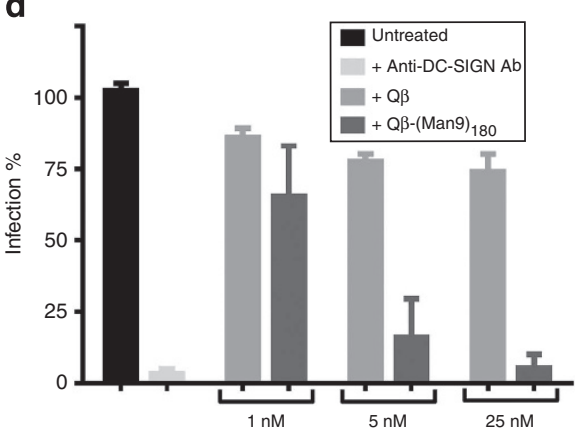

